\title{
RATIONING AND RATIONALITY IN THE NATIONAL HEALTH SERVICE
}


ECONOMIC ISSUES IN HEALTH CARE

General editors

Professor Gavin Mooney

Dr Alistair McGuire

Health Economics Research Unit Dept of Sociological Studies

Dept of Public Health

Wolfson College

Medical School

University of Oxford

Aberdeen AN9 2ZD

Oxford OX2 6UD

The Challenges of Medical Practice Variations

Edited by Tavs Folmer Andersen and Gavin Mooney (1990)

Private Exchange and Public Interest

By John Forbes (1990)

Rationing and Rationality in the National Health Service

Edited by Stephen J. Frankel and R. R. West (1993)

Just Managing - Power and Culture in the NHS

By Stephen Harrison, David J. Hunter, Gordon Marnoch and Christopher Pollitt (1993)

Dental Care: An Economic View

By David Parkin and Brian Yule (1990) 


\title{
RATIONING AND \\ RATIONALITY \\ IN THE NATIONAL \\ HEALTH SERVICE
}

The Persistence of Waiting Lists

\author{
Edited by
}

Stephen Frankel

and

Robert West

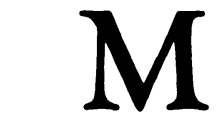

MACMILLAN 
(C) The editors and contributors 1993

All rights reserved. No reproduction, copy or transmission of this publication may be made without written permission.

No paragraph of this publication may be reproduced, copied or transmitted save with written permission or in accordance with the provisions of the Copyright Designs and Patents Act 1988, or under the terms of any licence permitting limited copying issued by the Copyright Licensing Agency, 90 Tottenham Court Road, London W1P 9HE.

Any person who does any unauthorised act in relation to this publication may be liable to criminal prosecution and civil claims for damages.

First published 1993 by

THE MACMILLAN PRESS LTD

Houndmills, Basingstoke, Hampshire RG21 2XS

and London

Companies and representatives

throughout the world

ISBN 978-0-333-49007-5

ISBN 978-1-349-22553-8 (eBook)

DOI 10.1007/978-1-349-22553-8

A catalogue record for this book is available from the British Library

Copy-edited and typeset by Cairns Craig Editorial, Edinburgh 


\section{Contents}

List of Tables and Figures vi

List of Contributors vii

1. The Origins of Waiting Lists 1

Stephen Frankel

2. Waiting Lists and Health Policy 15

John Cullis

3. Joining the Queue: Demand and Decision-making 42

Robert West

4. Opening the Gate: Referrals from Primary to Secondary Care

Stephen Farrow and David Jewell

5. Entering the Lobby: Access to Outpatient Assessment

Stephen Frankel and Margaret Robbins

6. And So to Bed: Access to Inpatient Services Ian Harvey

7. What is to be Done?

Stephen Frankel and Robert West

Bibliography

Index 


\section{List of Tables and Figures}

\section{TABLES}

1.1 Patients on selected in-patient waiting lists

1.2 Critical categories of patients on selected in-patient waiting lists

1.3 The index of interest in various diagnoses 11

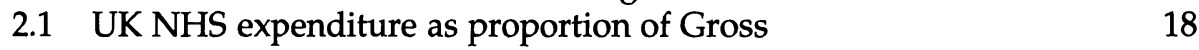
National Product (GNP)

2.2 NHS hospitals - number of in-patients on waiting list 19

2.3 An 'imputed' waiting list for California 24

2.4 A change in the 'implied' US waiting list 1979-82 26

2.5 Waiting lists and waiting times for Denmark 29

2.6 Illustrative service cost per QALY data 33

2.7 Mean and median waiting time (weeks) for typical waiting list conditions 1985

2.8 'Non-urgent' waiting in England and Wales (Sept. 1986) 35

2.9 Approaches to defining an optimum waiting list 39

\section{FIGURES}

1.1 Inpatient waiting lists and hospital throughput, England 4

2.1 Dealing with shortages: market v. state 17

2.2 California's medically uninsured, 1985

2.3 Health care systems: pictorial taxonomy 28

2.4 Waiting list management of QALYs 31 


\section{List of Contributors}

John Cullis

School of Social Sciences

University of Bath

Claverton Down

Bath BA2 7AY.

Stephen Farrow

Barnet Health Authority

Colindale Hospital

Colindale Avenue

London NW9 5HG.

Stephen Frankel

Health Care Evaluation Unit

Department of Epıdemiology and Public Health Medicine Canynge Hall

Whiteladies Road

Bristol BS8 2PR.

\section{Ian Harvey}

Health Care Evaluation Unit,

Department of Epidemiology and Public Health Medicine, Canynge Hall

Whiteladies Road

Bristol BS8 2PR.

\section{David Jewell}

General Practice Unit

Department of Epidemiology and Public Health Medicine

Canynge Hall

Whiteladies Road

Bristol BS8 2PR. 
viii

List of Contributors

Margaret Robbins

Health Care Evaluation Unit

Department of Epidemiology and Public Health Medicine

Canynge Hall

Whiteladies Road

Bristol BS8 2PR.

\section{Robert West}

Department of Epidemiology and Community Medicine University of Wales College of Medicine

Heath Park

Cardiff CF4 4XN. 